\title{
Regulation of Inositol 1,4,5-Trisphosphate Kinase Activity after Stimulation of Human T Cell Antigen Receptor
}

John B. Imboden and Gregory Pattison

Arthritis/Immunology Section and Department of Medicine, San Francisco Veterans Administration Medical Center and the University of California, San Francisco, California 94121

\begin{abstract}
Inositol 1,4,5-trisphosphate (Ins-1,4,5-P ${ }_{3}$ ), a $\mathrm{Ca}^{2+}$-mobilizing messenger, can be phosphorylated by a cytoplasmic kinase, yielding inositol 1,3,4,5-tetrakisphosphate (Ins-1,3,4,5-P $\mathbf{P}_{3}$. We observed that stimulation of the antigen receptor on a malignant human $T$ cell line, Jurkat, led to substantial, sustained increases in Ins-1,4,5-P $P_{3}$ and Ins $P_{4}$. The Ins-1,4,5-P $P_{3}$ kinase partially purified from resting Jurkat cells had a maximum velocity $\left(V_{\max }\right)$ of $0.09 \mathrm{nmol} / \mathrm{min} / \mathrm{mg}$ protein and an apparent Michaelis constant $\left(K_{\mathrm{m}}\right)$ of $0.2 \mu \mathrm{M}$. When the kinase was partially purified $10 \mathrm{~min}$ after stimulation of the antigen receptor or after the addition of phorbol myristate acetate, the $V_{\max }$ was increased twofold. The activity of the Ins-1,4,5- $\mathrm{P}_{3}$ kinase obtained from either resting or stimulated Jurkat cells was enhanced in vitro by increasing the concentration of free $\mathrm{Ca}^{2+}$ from 0.1 to $0.5 \mu \mathrm{M}$. These results indicate that the activity of the Ins-1,4,5- $\mathrm{P}_{3}$ kinase is regulated as a consequence of stimulating the $T$ cell antigen receptor.
\end{abstract}

\section{Introduction}

Transmembrane signaling by a variety of cell-surface receptors involves the release of $\mathrm{Ca}^{2+}$ from intracellular stores (reviewed in 1,2 ). Stimulation of these $\mathrm{Ca}^{2+}$-mobilizing receptors results in the hydrolysis of a membrane phospholipid, phosphatidylinositol-4,5-bisphosphate, generating diacylglycerol and inositol 1,4,5-trisphosphate (Ins-1,4,5- $\left.\mathrm{P}_{3}\right)^{1}(1,2)$. Diacylglycerol is an activator of protein kinase $C(2)$. Ins-1,4,5- $\mathrm{P}_{3}$, on the other hand, releases $\mathrm{Ca}^{2+}$ from the endoplasmic reticulum of broken cells and is thought to mediate receptor-induced intracellular $\mathrm{Ca}^{2+}$ mobilization within intact cells $(1,2)$.

The metabolism of Ins-1,4,5- $\mathrm{P}_{3}$ is complex. Specific phosphatases can sequentially remove phosphate groups from the inositol ring, eventually converting Ins-1,4,5- $\mathrm{P}_{\mathbf{3}}$ to free inositol (3). Alternatively, a cytoplasmic kinase that appears to have a wide tissue distribution can phosphorylate Ins-1,4,5- $\mathrm{P}_{3}$, yielding inositol 1,3,4,5-tetrakisphosphate (Ins-1,3,4,5-P 4 ) (4-6). Although increases in Ins-1,3,4,5- $\mathrm{P}_{4}$ and its immediate breakdown

Address correspondence to John B. Imboden, 111R, San Francisco VA Medical Center, San Francisco, CA 94121.

Received for publication 15 December 1986.

1. Abbreviations used in this paper: $\left[\mathrm{Ca}^{2+}\right] \mathrm{i}$, concentration of cytoplasmic free calcium; Ins-1,3,4- $\mathbf{P}_{\mathbf{3}}$, inositol 1,3,4-trisphosphate; Ins-1,3,4,5- $\mathbf{P}_{\mathbf{4}}$, inositol 1,3,4,5-tetrakisphosphate; Ins-1,4,5- $\mathrm{P}_{3}$, inositol 1,4,5-trisphosphate; MAb, monoclonal antibody; $\mathrm{T} 3 / \mathrm{Ti}$, $\mathrm{T}$ cell antigen receptor.

The Journal of Clinical Investigation, Inc.

Volume 79, May 1987, 1538-1541 product, inositol 1,3,4-trisphosphate (Ins-1,3,4-P $\mathbf{P}_{3}$ ), have been observed after receptor stimulation, it is not known what role, if any, the Ins-1,3,4,5- $\mathrm{P}_{4}$ pathway plays in receptor-mediated regulation of cellular activities (4-7). At a minimum, however, the existence of two pathways for the metabolism of Ins-1,4,5$P_{3}$ suggests a mechanism for differential control of the levels of this $\mathrm{Ca}^{2+}$-mobilizing messenger. In view of the investment of adenosine triphosphate in the formation of Ins-1,3,4,5- $\mathrm{P}_{4}$, it is also possible that Ins-1,3,4,5- $\mathrm{P}_{4}$ has a second messenger function of its own.

An important issue in defining the physiological role of the Ins-1,3,4,5- $\mathrm{P}_{4}$ pathway is whether the activity of the Ins-1,4,5$\mathrm{P}_{3}$ kinase is regulated as a consequence of receptor stimulation. To address this question, we examined the effects of stimulating the $\mathrm{T}$ cell antigen receptor $(\mathrm{T} 3 / \mathrm{Ti}$ ) and used a malignant humán $\mathrm{T}$ cell line, Jurkat, which has served as a model for studies of $\mathrm{T}$ cell activation (8-11). T3/Ti is composed of a disulfide-linked polymorphic heterodimer, $\mathrm{Ti}$, that is noncovalently associated with at least three invariant T3 polypeptides (12). Because T lymphocytes recognize specific antigen on the surface of specialized accessory cells, physiological stimulation of T3/Ti requires cell-cell contact (12). Under appropriate conditions, however, monoclonal antibodies (MAbs) with specificity for T3/ $T i$ can mimic the effects of antigen and activate $T$ lymphocytes (13). The addition of T3/Ti MAbs to Jurkat cells induces substantial increases in Ins $\mathrm{P}_{3}$ and concentration of cytoplasmic free calcium $\left(\left[\mathrm{Ca}^{2+}\right] \mathrm{i}\right)$ and stimulates the translocation of protein $\mathrm{ki}-$ nase $\mathrm{C}$ activity from the cytosol to a membrane fraction (8-11). The validity of the use of these MAb as receptor agonists is supported by the demonstrations that antigen-primed accessory cells stimulate antigen-specific $\mathrm{T}$ cell clones to generate InsP $_{3}$ and increase $\left[\mathrm{Ca}^{2+}\right] \mathrm{i}(14-16)$. Stewart et al. recently reported that permeabilized Jurkat cells have Ins-1,4,5- $\mathrm{P}_{3}$ kinase activity and observed an increase in the level of InsP $_{4} 10 \mathrm{~min}$ after the addition of a T3/Ti MAb (6). Herein we demonstrate that stimulation of $\mathrm{T} 3 / \mathrm{Ti}$ increases the activity of Ins-1,4,5- $\mathrm{P}_{3}$ kinase in Jurkat cells.

\section{Methods}

Cells and reagents. Jurkat E6-IL2 was passaged as described (17). C305, a mouse IgM kappa MAb, recognizes Ti on Jurkat (17). All chemicals were from Sigma Chemical Co., St. Louis, MO. $\left[{ }^{3} \mathrm{H}\right]$ Inositol $(17.1 \mathrm{Ci} /$ mmol) was obtained from New England Nuclear, Boston, MA. $\left[{ }^{3} \mathrm{H}\right]$ Ins1,4,5- $\mathrm{P}_{3}(1 \mathrm{Ci} / \mathrm{mmol}$; Amersham Corp., Arlington Heights, IL) was dried under nitrogen and resuspended in water before use. Protein measurements were by the colorimetric method of Bio-Rad Laboratories, Richmond, CA.

Separation of inositol polyphosphates by high-performance liquid chromatography (HPLC). Jurkat cells, labeled with $\left[{ }^{3} \mathrm{H}\right]$ inositol as de- 
scribed (18), were washed extensively, resuspended at $1.5 \times 10^{7} \mathrm{cells} / \mathrm{ml}$ in Hepes-buffered normal saline, and then incubated at $37^{\circ} \mathrm{C}$ with or without $\mathrm{C} 305(10 \mu \mathrm{g} / \mathrm{ml})$. At the end of the incubation period, cells were sedimented for $10 \mathrm{~s}$ in an Eppendorf 5414 microfuge. After aspiration of the medium, $1 \mathrm{ml}$ of ice-cold $10 \%(\mathrm{wt} / \mathrm{vol})$ trichloroacetic acid was added to the cellular pellet, and samples were incubated for $10 \mathrm{~min}$ on ice. After removal of insoluble material by a $900 \mathrm{~g}$ centrifugation for 10 min, the supernatant was extracted with 6 vol of diethyl ether and then neutralized. Inositol polyphosphates were separated by a modification of the HPLC method of Irvine et al. $(4,7)$ using a Whatman Partisal 10 SAX column $(0.46 \times 25 \mathrm{~cm}, 10-\mu \mathrm{m}$ particle size $)$ and a guard column packed with Whatman Pellicular anion exchanger. Following sample injection, the column was washed for $10 \mathrm{~min}$ with water and then subjected to increasing concentrations of ammonium formate buffer (adjusted to $\mathrm{pH} 3.7$ with phosphoric acid) with a flow rate of $1.2 \mathrm{ml} / \mathrm{min}$. Following a linear gradient to $0.8 \mathrm{M}$ ammonium formate over $30 \mathrm{~min}$, Ins-1,3,4- $\mathrm{P}_{3}$ and Ins-1,4,5- $\mathrm{P}_{3}$ were sequentially eluted in $0.8 \mathrm{M}$ ammonium formate and collected in 0.5 -min fractions. After $18 \mathrm{~min}$ at 0.8 $\mathrm{M}$, the concentration of ammonium formate was increased to $2 \mathrm{M}$ by a linear gradient over $15 \mathrm{~min}$, and $\mathrm{InsP}_{4}$ was then collected in 1-min fractions. ${ }^{3} \mathrm{H}$ radioactivity was quantified by liquid scintillation counting in Aquasol (New England Nuclear). Under these conditions peak elution times for Ins-1,3,4- $\mathrm{P}_{3}$, Ins-1,4,5- $\mathrm{P}_{3}$, and $\mathrm{InsP}_{4}$ were 48, 52, and $75 \mathrm{~min}$, respectively, from the time of sample injection. Ins-1,4,5- $\mathrm{P}_{3}$ in samples was identified on the basis of identity with the elution time of the $\left[{ }^{3} \mathrm{H}\right] \mathrm{Ins}-$ 1,4,5- $\mathrm{P}_{3}$ standard. As described $(7,19)$, Ins-1,3,4- $\mathrm{P}_{3}$ was identified by an elution time intermediate between adenosine triphosphate and Ins-1,4,5$\mathrm{P}_{3}$. To determine the elution time of $\operatorname{InsP}_{4}$, we prepared samples containing Ins $\mathrm{P}_{4}$ by adding $\left[{ }^{3} \mathrm{H}\right]$ Ins-1,4,5- $\mathrm{P}_{3}$ to saponin-permeabilized Jurkat cells by the method of Stewart et al. (6). As it has not been demonstrated that phosphorylation of Ins-1,4,5- $\mathrm{P}_{3}$ occurs on the 3 position under these conditions, we will refer to this product as simply InsP $\mathrm{P}_{4}$.

Partial purification of Ins-1,4,5- $P_{3}$ kinase. Ins-1,4,5- $\mathrm{P}_{3}$ kinase was partially purified from Jurkat cells by the method of Hansen et al. (5). $10^{8}$ Jurkat cells were incubated for $10 \mathrm{~min}$ at $37^{\circ} \mathrm{C}$ in $1 \mathrm{ml}$ of Hepesbuffered saline solution alone or with either MAb C305 $(10 \mu \mathrm{g} / \mathrm{ml})$ or phorbol myristate acetate (PMA) $(50 \mathrm{ng} / \mathrm{ml})$. Cells were sedimented for $15 \mathrm{~s}$ in an Eppendorf 5414 centrifuge, resuspended in $400 \mu \mathrm{l}$ of ice-cold buffer containing $5 \mathrm{mM}$ Tris, pH 7.5, $1 \mathrm{mM}$ EGTA, $2 \mathrm{mM} \mathrm{MgCl}_{2}, 2$ $\mathrm{mM}$ dithiothreitol, and $5 \mathrm{mM}$ sodium pyrophosphate, and then homogenized with 65 strokes in a Potter Elvehjem tissue grinder. Following the addition of $100 \mu \mathrm{l}$ of $1 \mathrm{M}$ sucrose and the removal of particulate material by a 10 -min centrifugation in an Eppendorf 5414 microfuge, the homogenate was subjected to centrifugation at $100,000 \mathrm{~g}$ for $90 \mathrm{~min}$. The resulting supernatant was fractionated with ammonium sulfate, and a 23-40\% fraction dialyzed overnight against $10 \mathrm{mM}$ Tris/ $\mathrm{HCl}, \mathrm{pH} 7.5$, $2 \mathrm{mM} \mathrm{MgCl}$, and $2 \mathrm{mM}$ dithiothreitol.

Assay for Ins-1,4,5- $P_{3}$ kinase activity. The assay for Ins-1,4,5- $\mathrm{P}_{3}$ kinase activity was performed according to published methods $(4,5)$. Assays were performed at $37^{\circ} \mathrm{C}$ in a final volume of $40 \mu$ land were initiated by the addition of $10 \mu \mathrm{g}$ of the Ins-1,4,5-P $\mathrm{P}_{3}$ kinase preparation. The reaction buffer contained $\left[{ }^{3} \mathrm{H}\right]$ Ins-1,4,5- $\mathrm{P}_{3}$ as indicated, $50 \mathrm{mM}$ Tris, $\mathrm{pH}$ 7.5, $5 \mathrm{mM}$ ATP, $2 \mathrm{mM}$ sodium pyrophosphate, $5 \mathrm{mM} \mathrm{EGTA}$, and $\mathrm{CaCl}_{2}$ to give the indicated $\left[\mathrm{Ca}^{2+}\right]$. As noted previously, this concentration of sodium pyrophosphate minimizes residual Ins-1,4,5- $\mathrm{P}_{3}$ phosphomonoesterase activity without inhibiting Ins-1,4,5- $\mathrm{P}_{3}$ kinase activity (5). The reaction was terminated by the addition of $1 \mathrm{ml}$ of ice-cold $10 \%$ trichloroacetic acid. $\left[{ }^{3} \mathrm{H}\right] \mathrm{Ins}-1,4,5-\mathrm{P}_{3}$ and $\mathrm{InsP}_{4}$ were separated either by a modification of the HPLC method described above or by elution from Dowex 1-X8 columns in formate form (100-200 mesh; Bio-Rad Laboratories) in, respectively, $20 \mathrm{ml}$ of $0.8 \mathrm{M}$ ammonium formate plus $0.1 \mathrm{M}$ formic acid and $10 \mathrm{ml}$ of $2 \mathrm{M}$ ammonium formate plus $0.1 \mathrm{M}$ formic acid (4).

\section{Results}

To confirm that the Ins-1,4,5- $\mathrm{P}_{\mathbf{3}}$ kinase is active in Jurkat cells following perturbation of $\mathrm{T} 3 / \mathrm{Ti}$, we stimulated intact $\left[{ }^{3} \mathrm{H}\right]$ inositol-labeled Jurkat cells and resolved the extracted $\left[{ }^{3} \mathrm{H}\right]$ inositol polyphosphates by HPLC (Fig. 1). The addition of C305, a MAb with specificity for T3/Ti on Jurkat (17), led to prompt increases in $\left[{ }^{3} \mathrm{H}\right]$ Ins- $1,4,5-\mathrm{P}_{3}$ and $\left[{ }^{3} \mathrm{H}\right]$ Ins $\mathrm{P}_{4}$. The level of $\left[{ }^{3} \mathrm{H}\right]$ Ins- $1,4,5-\mathrm{P}_{3}$ reached a peak by $60 \mathrm{~s}$ and then fell over the succeeding minute to a plateau that remained elevated for $>15$ min. $\left[{ }^{3} \mathrm{H}\right] \mathrm{InsP}_{4}$ increased for $\sim 5 \mathrm{~min}$ to steady-state level that was substantially higher than that of $\left[{ }^{3} \mathrm{H}\right] \mathrm{Ins}-1,4,5-\mathrm{P}_{3}$. After a 30-s lag, an increase in $\left[{ }^{3} \mathrm{H}\right]$ Ins-1,3,4- $\mathrm{P}_{3}$ was detected. Because the only known source of Ins $\mathrm{P}_{4}$ and Ins-1,3,4- $\mathrm{P}_{3}$ requires Ins1,4,5- $\mathrm{P}_{3}$ kinase activity (4-6), these results indicate that, following stimulation of $\mathrm{T} 3 / \mathrm{Ti}$ on Jurkat cells, a substantial proportion of the Ins-1,4,5- $\mathrm{P}_{3}$ generated is phosphorylated to Ins $\mathrm{P}_{4}$.

Permeabilized Jurkat cells have Ins-1,4,5- $\mathrm{P}_{3}$ kinase activity (6). As has been observed in rat brain and liver, this enzyme is soluble and can be partially purified by ammonium sulfate fractionation of the supernatant obtained from an ultracentrifugation of cell homogenates $(4,5)$. The Ins-1,4,5- $\mathrm{P}_{3}$ kinase partially purified from resting Jurkat cells in this manner had a maximum velocity $\left(V_{\max }\right)$ of $0.09 \mathrm{nmol} / \mathrm{min} / \mathrm{mg}$ protein and an apparent Michaelis constant $\left(K_{\mathrm{m}}\right)$ of $0.2 \mu \mathrm{M}$ (Fig. 2). The latter value is in approximate agreement with the reported $K_{\mathrm{m}}(0.6 \mu \mathrm{M})$ of the Ins-1,4,5- $\mathrm{P}_{3}$ kinase activity of rat brain cytosol (4). To determine whether the Ins $\mathrm{P}_{4}$ pathway is regulated as a result of stimulating $\mathrm{T} 3 / \mathrm{Ti}$, we compared the kinetics of Ins-1,4,5- $\mathrm{P}_{3}$ kinase obtained from resting Jurkat cells and from cells stimulated by C305 (Fig. 2, $A$ and $B$ ). Within $10 \mathrm{~min}$, stimulation of T3/Ti by the MAb led to a twofold increase in the $V_{\max }$ of the Ins-1,4,5- $\mathrm{P}_{3}$ kinase without a detectable change in $K_{\mathrm{m}}$. A comparable increase in kinase activity was observed after treating Jurkat cells for 10 min with PMA, an activator of protein kinase C (Fig. 2, $A$ and $C)$. We observed similar T3/Ti- and PMA-induced increases in the Ins-1,4,5- $\mathrm{P}_{3}$ kinase activity of unfractionated Jurkat cytosol (not shown).

There are conflicting reports as to the effect of the concentration of $\left[\mathrm{Ca}^{2+}\right]$ on Ins-1,4,5- $\mathrm{P}_{3}$ kinase activity from other cells in vitro $(4,22)$. In studies of Ins-1,4,5- $\mathrm{P}_{3}$ kinase from Jurkat

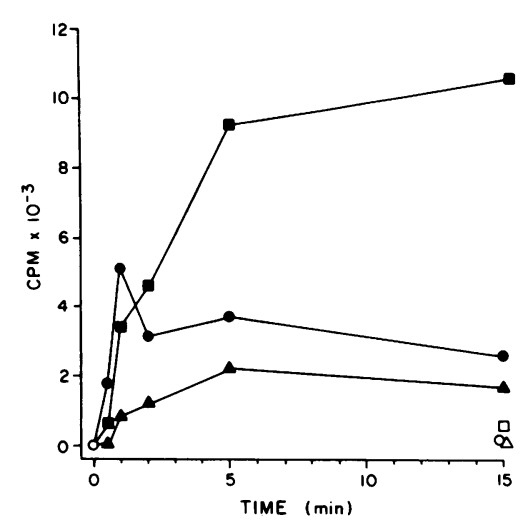

Figure 1. Time course of the increases in Ins1,4,5- $\mathrm{P}_{3}$ (closed circles), Ins $\mathrm{P}_{4}$ (closed boxes), and Ins-1,3,4-P $\mathrm{P}_{3}$ (closed triangles) after the addition of a T3/Ti MAb to Jurkat cells. C305, a MAb with specificity for $\mathrm{T} 3 / \mathrm{Ti}$, was added at time 0 to $\left[{ }^{3} \mathrm{H}\right]$ inositol-labeled Jurkat cells, and aliquots containing 1.5 $\times 10^{7}$ cells removed subsequently for each data point. The indicated time points are the intervals from the addition of $\mathrm{C} 305$ to the lysis of cells in trichloroacetic acid. Inositol polyphosphate levels from $1.5 \times 10^{7}$ unstimulated cells incubated concomitantly for $15 \mathrm{~min}$ are shown (open circles, open boxes, open triangles). $\left[{ }^{3} \mathrm{H}\right]$ Inositol polyphosphates were extracted, separated by HPLC, and quantified as described in Methods. Results are expressed as the change in cpm from unstimulated cells at time 0 . The levels of Ins-1,4,5- $\mathrm{P}_{3}, \mathrm{InsP}_{4}$, and Ins-1,3,4- $\mathrm{P}_{3}$ in these unstimulated cells were 89,618 , and $66 \mathrm{cpm}$, respectively. 

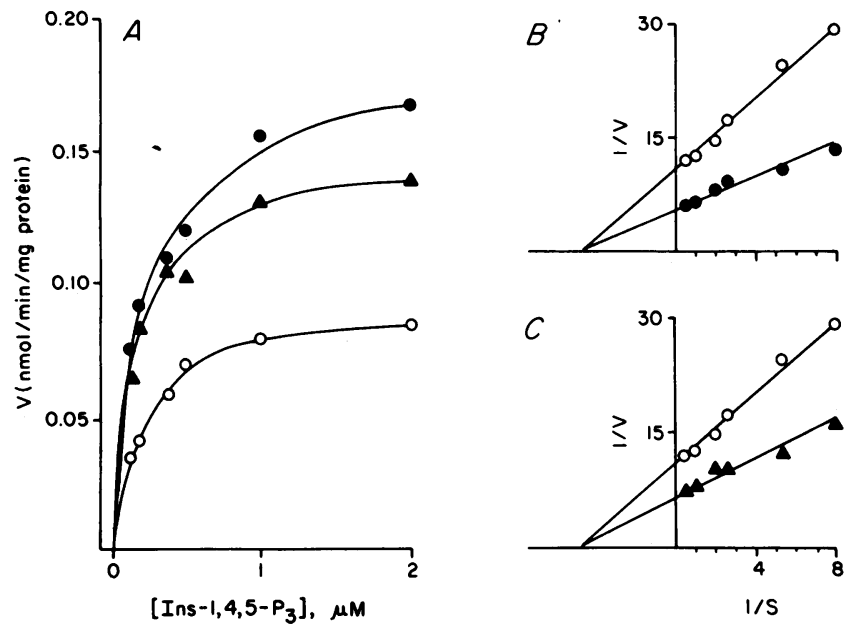

Figure 2. The relationship between kinase activity $(V)$ and substrate concentration $(S)$ for Ins-1,4,5- $\mathrm{P}_{3}$ kinase prepared from unstimulated Jurkat cells (open circles); Jurkat cells stimulated for $10 \mathrm{~min}$ with C305, a T3/Ti MAb (closed circles), and Jurkat cells treated for 10 min with PMA $(50 \mathrm{ng} / \mathrm{ml})$ (closed triangles). $(A)$ Ins-1,4,5- $\mathrm{P}_{3}$ kinase was assayed as described in Methods with $\mathrm{CaCl}_{2}$ added to give a calculated free $\mathrm{Ca}^{2+}$ concentration of $0.5 \mu \mathrm{M}(23)$. After $3 \mathrm{~min}$, the reaction was terminated by the addition of trichloroacetic acid, and Ins-1,4,5$\mathrm{P}_{3}$ and InsP $\mathrm{P}_{4}$ were separated by HPLC. ( $B$ and $C$ ) Lineweaver-Burk plots of the data shown in $(A)$.

cells, we observed a stimulatory effect on kinase activity when $\left[\mathrm{Ca}^{2+}\right]$ was increased from $0.1 \mu \mathrm{M}$ to $1 \mu \mathrm{M}$ with a maximal effect at $0.5 \mu \mathrm{M}$ (Fig. 3). This effect of $\left[\mathrm{Ca}^{2+}\right]$ was observed with Ins1,4,5- $\mathrm{P}_{3}$ kinase prepared both from resting cells and from cells exposed to $\mathrm{C} 305$. Increasing $\left[\mathrm{Ca}^{2+}\right]$ to $>1 \mu \mathrm{M}$ had an inhibitory effect on kinase activity (Fig. 3).

\section{Discussion}

The addition of a T3/Ti MAb to the T cell line, Jurkat, leads to substantial, sustained increases in Ins-1,4,5- $\mathrm{P}_{3}$, Ins $\mathrm{P}_{4}$, and Ins$1,3,4-P_{3}$. Studies of the kinetics of Ins-1,4,5- $\mathrm{P}_{3}$ kinase partially purified from Jurkat cells demonstrate that the $V_{\max }$ of this enzyme is increased approximately twofold within $10 \mathrm{~min}$ of stimulating $\mathrm{T} 3 / \mathrm{Ti}$. These results establish that the activity of the Ins$1,4,5-\mathrm{P}_{3}$ kinase can be regulated as a consequence of receptor stimulation.

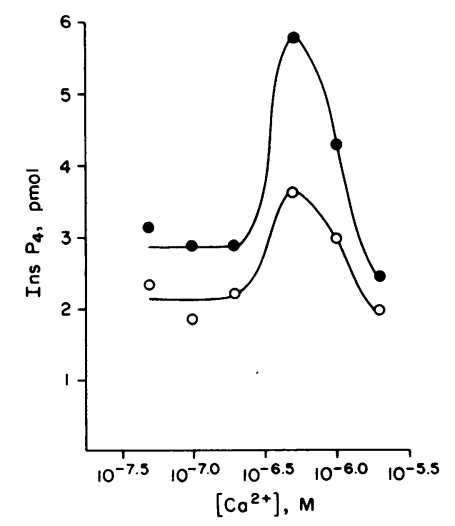

Figure 3. Effect of the concentration of free $\mathrm{Ca}^{2+}$ on the activity of the Ins-1,4,5- $\mathrm{P}_{3}$ kinase prepared from unstimulated Jurkat cells (open circles) and Jurkat cells exposed to C 305 for $10 \mathrm{~min}$ (closed circles). Ins$1,4,5-P_{3}$ kinase activity was assayed for 5 min with sufficient $\mathrm{CaCl}_{2}$ added to give the indicated free $\mathrm{Ca}^{2+}$ concentration (23). The concentration of $\left[{ }^{3} \mathrm{H}\right]$ Ins-1, 4,5- $\mathrm{P}_{3}$ was $1 \mu \mathrm{M}$. $\left[{ }^{3} \mathrm{H}\right]$ Ins- $1,4,5-\mathrm{P}_{3}$ and $\mathrm{InsP}_{4}$ were separated by anion exchange chromatography using Dowex 1 -X8 columns in formate form.
The mechanism by which stimulation of $\mathrm{T} 3 / \mathrm{Ti}$ leads to an increase in the $V_{\max }$ of the Ins-1,4,5- $\mathrm{P}_{3}$ kinase is not established but presumably involves either a direct modification of the kinase (or a cofactor) or an increase in the amount of soluble kinase. The ability of PMA to mimic the effects of T3/Ti MAb on the $V_{\max }$ of the Ins-1,4,5- $\mathrm{P}_{3}$ kinase raises the possibility that the increase in kinase activity may be a consequence of T3/Ti-mediated activation of protein kinase $C$. Whether the Ins-1,4,5- $\mathrm{P}_{3}$ kinase itself is actually a substrate for protein kinase $C$, of course, cannot be determined until the Ins-1,4,5- $\mathrm{P}_{3}$ kinase has been purified. Interestingly, in platelets, activated protein kinase $C$ augments the conversion of Ins-1,4,5- $\mathrm{P}_{3}$ to inositol-1,4-bisphosphate by phosphorylating the Ins-1,4,5- $\mathrm{P}_{3}$ 5'-phosphomonoesterase $(24,25)$.

Our studies, together with those of Biden and Wollheim (22), indicate that changes in $\left[\mathrm{Ca}^{2+}\right]$ can increase Ins-1,4,5- $\mathrm{P}_{3}$ kinase activity in vitro. Increasing $\left[\mathrm{Ca}^{2+}\right]$ influences the activity of kinase obtained from stimulated as well as resting Jurkat cells. Maximal activity occurs at $0.5-1.0 \mu \mathrm{M}$ free $\mathrm{Ca}^{2+}$, within the range achieved by receptor stimulation of intact, quin2-loaded Jurkat cells (810). Following perturbation of $\mathrm{T} 3 / \mathrm{Ti}$ on intact Jurkat cells, therefore, the activity of the Ins-1,4,5- $\mathrm{P}_{3}$ kinase may be enhanced by two distinct mechanisms with additive effects: the receptorstimulated increase in $V_{\max }$ and a direct effect of the receptormediated increase in $\left[\mathrm{Ca}^{2+}\right] \mathrm{i}$.

Because the activity of the Ins-1,4,5- $\mathrm{P}_{3}$ kinase is increased as a consequence of stimulating $\mathrm{T} 3 / \mathrm{Ti}$, it is likely that the $\mathrm{InsP}_{4}$ pathway plays an important role in signal transduction by $\mathrm{T} 3$ / Ti. T3/Ti-mediated signaling, therefore, either may require that the levels of Ins-1,4,5- $\mathrm{P}_{3}$ be regulated within certain limits or it may use the products of the $\mathrm{InsP}_{4}$ pathway as second messengers. $\sim 2 \mathrm{~h}$ of ligand occupancy of $\mathrm{T} 3 / \mathrm{Ti}$ are required to commit Jurkat cells to the production of interleukin 2, suggesting that ongoing signal generation by $\mathrm{T} 3 / \mathrm{Ti}$ is required for activation (26). Perturbation of T3/Ti by MAb leads to an increase in $\left[\mathrm{Ca}^{2+}\right] \mathrm{i}$, which is sustained in quin2-loaded Jurkat cells for $>30$ min and which has been identified as a signal for activation (810). The initial peak increase in $\left[\mathrm{Ca}^{2+}\right]$ i that occurs within $60 \mathrm{~s}$ of the addition of $\mathrm{T} 3 / \mathrm{Ti} \mathrm{MAb}$ is due to the mobilization of intracellular $\mathrm{Ca}^{2+}$ and is presumably mediated by Ins-1,4,5- $\mathrm{P}_{3}$ (10). The T3/Ti-mediated increase in $\left[\mathrm{Ca}^{2+}\right] \mathrm{i}$ is then sustained by uptake of extracellular $\mathrm{Ca}^{2+}$, probably through voltage-independent $\mathrm{Ca}^{2+}$ channels $(27,28)$. One possible function of the prolonged $\mathrm{T} 3 / \mathrm{Ti}$-mediated increase in inositol polyphosphates may be to regulate sustained increases in $\left[\mathrm{Ca}^{2+}\right]$ i. Alternatively, these compounds may activate other, as yet unidentified, signaling pathways.

\section{Acknowledgments}

We thank Dr. A. Weiss for the kind gifts of Jurkat E6-IL-2 and C305, Dr. B. Halloran and Dr. R. Nissenson for helpful discussions, and Ms. V. Lopez and D. Go for preparation of this manuscript.

Dr. Imboden is a Pfizer Scholar. This work was supported in part by the Veterans Administration and by grants from the Northern California Arthritis Foundation and Universitywide Task Force on AIDS.

\section{References}

1. Berridge, M. J., and R. F. Irvine. 1984. Inositol trisphosphate, a novel second messenger in cellular signal transduction. Nature (Lond.). 312:315-321. 
2. Nishizuka, Y. 1986. Studies and perspectives of protein kinase C. Science (Wash. DC). 233:305-312.

3. Downes, C., M. Mussat, and R. Michell. 1982. The inositol trisphosphate phosphomonoesterase of human erythrocytes membrane. Biochem. J. 203:169-177.

4. Irvine, R. F., A. J. Letcher, J. P. Heslop, and M. J. Berridge. 1986. The inositol tris/tetrakisphosphate pathway: demonstration of Ins$(1,4,5) \mathrm{P}_{3}$ 3-kinase activity in animal tissues. Nature (Lond.). 320:631634.

5. Hansen, C. A., S. Mah, and J. R. Williamson. 1986. Formation and metabolism of inositol 1,3,4,5-tetrakisphosphate in liver. J. Biol. Chem. 261:8100-8103.

6. Stewart, S. J., V. Prpic, F. S. Powers, S. B. Bocckino, R. E. Isaacks, and J. H. Exton. 1986. Perturbation of the human T cell antigen receptorT3 complex leads to the production of inositol tetrakisphosphate. Evidence for converson from inositol trisphosphate. Proc. Natl. Acad. Sci. USA. 83:6098-6102.

7. Irvine, R. F., E. E. Anggard, A. J. Letcher, and C. P. Downes. 1985. Metabolism of inositol 1,4,5-trisphosphate and inositol 1,3,4-trisphosphate in rat parotid glands. Biochem. J. 229:505-511.

8. Weiss, A., J. Imboden, D. Shoback, and J. Stobo. 1984. Role of T3 surface molecules in human T-cell activation: T3-dependent activation results in an increase in cytoplasmic free calcium. Proc. Natl. Acad. Sci. USA. 81:4169-4173.

9. Imboden, J., A. Weiss, and J. Stobo. 1985. The antigen receptor on a human $\mathrm{T}$ cell line initiates activation by increasing cytoplasmic free calcium. J. Immunol. 134:663-665.

10. Imboden, J., and J. Stobo. 1985. Transmembrance signalling by the T cell antigen receptor. J. Exp. Med. 161:446-456.

11. Ledbetter, J. A., C. H. June, P. J. Martin, C. E. Spooner, J. A. Hansen, and K. E. Meier. 1986. Valency of CD3 binding and internalization of the CD3 cell-surface complex control $\mathrm{T}$ cell responses to second signals: distinction between effects on protein kinase $\mathrm{C}$, cytoplasmic free calcium, and proliferation. J. Immunol. 136:3945-3952.

12. Meuer, S., O. Acuto, T. Hercend, S. Schlossman, and E. Reinherz. 1984. The human T-cell receptor. Annu. Rev. Immunol. 2:23-50.

13. Meuer, S., J. C. Hodgdon, R. E. Hussey, J. P. Protentis, S. F. Schlossman, and E. L. Reinherz. 1983. Antigen-like effects of monoclonal antibodies directed at receptors on human T cell clones. J. Exp. Med. 158:988-993.

14. Imboden, J., C. Weyland, and J. Goronzy. 1987. Antigen recognition by a human $T$ cell clone leads to an increase in inositol trisphosphate. J. Immunol. In press.

15. Nisbet-Brown, E., R. K. Cheung, J. W. W. Lee, and E. W. Gelfand.
1985. Antigen-dependent increase in cytosolic free calcium in specific human T-lymphocyte clones. Nature (Lond.). 316:545-547.

16. Shapiro, D., B. Adams, and J. Niederhbuber. 1985. Antigenspecific $\mathrm{T}$ cell activation results in an increase in cytoplasmic free calcium. J. Immunol. 135:2256-2261.

17. Weiss, A., and J. Stobo. 1984. Requirement for the coexpression of $\mathrm{T} 3$ and the $\mathrm{T}$ cell antigen receptor on a malignant human $\mathrm{T}$ cell line. J. Exp. Med. 160:1284-1299.

18. Imboden, J., D. Shoback, G. Pattison, and J. Stobo. 1986. Cholera toxin inhibits the $\mathrm{T}$ cell antigen receptor-mediated increases in inositol and cytoplasmic free calcium. Proc. Natl. Acad. Sci. USA. 83:56735677.

19. Wollheim, C. B., and T. J. Biden. 1986. Second messenger function of inositol 1,4,5-trisphosphate. J. Biol. Chem. 261:8314-8319.

20. Castagna, M., Y. Takai, K. Kaibuchi, K. Sano, U. Kikkawa, and Y. Nishizuka. 1982. Direct activation of calcium-activated, phospholipiddependent protein kinase by tumor-promoting phorbol esters. J. Biol. Chem. 257:7847-7851.

21. Niedel, J. E., L. J. Kuhn, and G. R. Vandenbark. 1983. Phorbol diester receptor copurifies with protein kinase C. Proc. Natl. Acad. Sci. USA. 80:36-40.

22. Biden, T. J., and C. B. Wollheim. $\mathrm{Ca}^{2+}$ regulates the inositol tris/ tetrakisphosphate pathway in intact and broken preparations of insulinsecreting RINm5F cells. J. Biol. Chem. 261:11931-11934.

23. Mills, G. B., R. K. Cheung, S. Grinstein, and E. W. Gelfand. 1985. Interleukin 2-induced lymphocyte proliferation is independent of increases in cytosolic-free calcium concentrations. J. Immunol. 134:24312435.

24. Connolly, T. M., W. J. Lawing, and P. W. Majerus. 1986. Protein kinase $C$ phosphorylates human platelet inositol trisphosphate 5 '-phosphomonoesterase, increasing the phosphatase activity. Cell. 46:951-958.

25. Molina y Vedia, L. M., and E. G. Lapetina. 1986. Phorbol 12,13dibutyrate and 1-oleyl-2-acetyldiacylglycerol stimulate inositol trisphosphate dephosphorylation in human platelets. J. Biol. Chem. 261:1049310495.

26. Weiss, A., R. Shields, M. Newton, B. Manger, and J. Imboden. 1987. Ligand-receptor interactions required for commitment to the activation of the interleukin-2 gene. J. Immunol. In press.

27. Kuno, M., J. Goronzy, C. M. Weyand, and P. Gardner. 1986. Single-channel and whole-cell recordings of mitogen-regulated inward currents in human cloned helper T lymphocytes. Nature (Lond.). 323: 269-273.

28. Oettgen, H., C. Terhorst, L. Cantley, and P. Rosoff. 1985. Stimulation of the T3-T cell receptor complex induces a membrane-potentialsensitive calcium influx. Cell. 40:583-590. 